\title{
Potassium Supplying Power of the Major Upland Inceptisols of Puerto Rico'
}

\author{
Fernando Abruña ${ }^{2}$
}

\begin{abstract}
Capacity of the nine most extensive upland Inceptisols of Puerto Rico to supply potassium $(K)$ was determined through intensive cropping in pots with Pangola grass during 4 consecutive years. In addition, field experiments were conducted on two of these soils, Múcara and Pandura, for comparison.

Seven of the Inceptisols tested formed under a udic moisture regime. They supplied an average of $279 / \mathrm{kg}$ of $\mathrm{K} / \mathrm{ha}$ to Pangola grass during the first year, and then dropped to 110,114 , and $93 \mathrm{~kg} / \mathrm{ha}$ for the second, third and fourth years, respectively. The average of $106 \mathrm{~kg} / \mathrm{ha}$ for the last 3 years probably represents the long term capacity of this group to supply $\mathrm{K}$ to plants.

The amount of $\mathrm{K}$ released by Múcara and Pandura soils (both udic Inceptisols) in the field experiments agreed fairly well with values obtained in the pot experiments.

Two of the Inceptisols tested formed under a ustic moisture regime released and average of $507 \mathrm{~kg}$ of $\mathrm{K} /$ ha during the first year, and then 254, 233 , and $140 \mathrm{~kg} / \mathrm{ha}$ the last 3 years. The average $\mathrm{K}$ release per year for the last 3 years was $209 \mathrm{~kg} / \mathrm{ha}$. However, the long range $\mathrm{K}$ supplying capacity of these soils is probably lower than this value.

The exchangeable $K$ values obtained at the beginning of the pot experiment were significantly correlated with the amount of $\mathrm{K}$ extracted by Pangola grass during the first year of cropping in pots, whereas the $\mathrm{HNO}_{3}$-Soluble $\mathrm{K}$ values were correlated with the average release of $\mathrm{K}$ during the last 3 cropping years.
\end{abstract}

\section{INTRODUCTION}

According to Wiklander (20) potassium occurs in soils in four different forms: exchangeable, in soil solution, fixed and contained in the mineral matrixes. Rich (16) postulates that most of the potassium that is readily available to plants exists as exchangeable ions, and as this form is exhausted by crops it is replaced at varying rates by the $\mathrm{K}$-bearing minerals in the soil. The amount of exchangeable $\mathrm{K}$ in soils depends on the origin, age, mechanical composition and rates of fertilization. There is considerable information on the $\mathrm{K}$-supplying power of soils from the temperate region $(6,7,10,11,14,15,17)$. This research work has been carried out mainly in U.S.A. under greenhouse conditions. In most of them exchangeable and $\mathrm{HNO}_{3}$-soluble $\mathrm{K}$ has been correlated with plant uptake. In only few cases the exchangeable potassium values did not correlate with plant uptake (15).

There is plenty of available information on potassium fertilization on

'This research was carried out cooperatively between the Science and Education Idministration, USDA and the Agricultural Experiment Station, College of Agricultural Science, Mayagüez Campus, University of Puerto Ríco, Rio Piedras, P.R.

${ }^{2}$ Soil Scientist, Federal Research, Science and Education Administration, USDA, Río Piedras, P.R. 
tropical soils $(5,8,18,19)$. On the other hand, the capacity of tropical soils to supply $K$ to crops has been investigated in a fragmentary way with no bearing to the new system of soil taxonomy $(3,4,5,12,13)$.

Inceptisols are extensively used throughout the tropics and they are more so in the humid than on semihumid regions. These soils are extensively used in Ghana for cocoa growing and in Tanzania for small grain farming (5).

The upland Inceptisols of Puerto Rico cover about 185,000 ha in the humid mountain region (the area under udic moisture regime). They include soils of the Múcara, Quebrada, Caguabo, Juncos, Pandura and Utuado series. About 50,000 ha in the semiarid uplands (ustic moisture regime) includes soils of the Descalabrado and Jácana series. Except for the Pandura and Utuado soils these soils are derived mainly from volcanic material, predominantly andesitic tuffs. Pandura and Utuado soils are derived from quartz diorites. Most of the Inceptisols of the semi-arid (ustic) region are used as range; those of the humid (udic) uplands are used for pastures, tobacco, root crops and extensively managed coffee.

Vicente-Chandler et al. (19) showed that intensively managed tropical grasses under cutting management took up about $420 \mathrm{~kg}$ of $\mathrm{K} / \mathrm{ha}$. yr and responded to applications of $335 \mathrm{~kg}$ of $\mathrm{K} / \mathrm{ha}$. yr on Ultisols. Abruña et al. (1) found that intensively managed coffee responded to applications of $335 \mathrm{~kg}$ of K/ha. yr. Caro-Costas et al. (9) found that plantains grown on an Ultisol responded to the application of $450 \mathrm{~kg}$ of $\mathrm{K} / \mathrm{ha}$. yr.

Abruña et al. (2) found that on the average, the major Ultisols and Oxisols of Puerto Rico supplied 250 of $\mathrm{kg}$ of $\mathrm{K} / \mathrm{ha}$. yr to intensively managed grasses during the first year and 90 and $50 \mathrm{~kg}$ of $\mathrm{K} / \mathrm{ha}$. $\mathrm{yr}$, respectively over a subsequent 3 yr period.

There is little information available on the $\mathrm{K}$ supplying capacity of the upland Inceptisols of Puerto Rico, which are typical of vast areas in the tropics and have a great potential for meat and milk production.

This paper present the results of a $4 \mathrm{yr}$ experiment carried out to determine the capacity of the major upland Inceptisols of Puerto Rico to supply $\mathrm{K}$ to intensively managed grasses.

\section{MATERIALS AND METHODS}

Soil samples were taken to a depth of $30 \mathrm{~cm}$ from each of 111 sites, 89 representing the Inceptisols of the humid uplands (Múcara, Sabana, Caguabo, Juncos, Pandura and Utuado soils) and 22 the semi-arid uplands, (Descalabrado and Jácana soils). The number of samples representing each soil series was in proportion to the area covered by the soil and ranged from 7 for the Utuado soils which covers 10,000 ha to 25 for Múcara soils which cover 67,000 ha. 
The soil from each site was air dried, sieved, limed to about $80 \%$ base saturation and $15 \mathrm{~kg}$ placed in 12 liter pots. The amount of surface and subsurface soil potted for each site was in proportion to the actual thickness of each layer as it occurred in the field. The surface area of each pot was $.545 \mathrm{sq} f t$ equivalent to $\frac{1}{80,000}$ of an acre. The weight of a furrow slice for each soil was determined using volume weight values for each soil layer. This value was used to convert the pot data into per

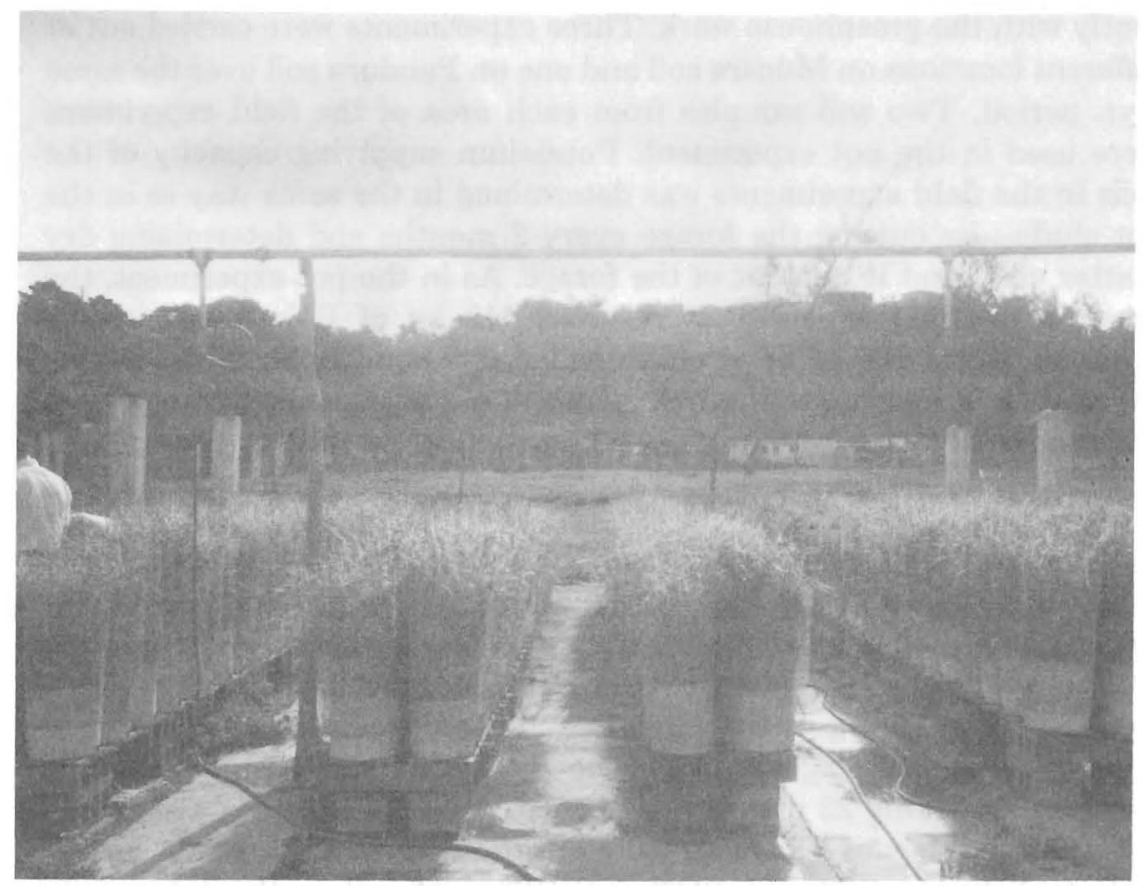

FIG. 1.-Layout of experimental plots. A wire mesh was used to confine grass growth to the pot area.

hectare basis. Phosphorus (as triple super) was applied at the rate of 112 $\mathrm{kg} / \mathrm{ha}$ once every year and $\mathrm{N}$ (as urea) at the rate of $673 / \mathrm{kg}$ of $\mathrm{N} / \mathrm{ha}$. yr divided in 6 equal applications yearly, one after each cutting.

Pangola grass was planted in all pots. The experiment was initiated when a solid stand was established (figure 1). The Pangolagrass was harvested every 2 months, dried, and weighed to determine dry matter yields and the $\mathrm{K}$ content.

The soil was thoroughly wetted twice weekly by flooding the pots for 2 hours. The excess water was then drained from each pot and later used 
to irrigate the same pot, so that $\mathrm{K}$ in the leachates was returned to the soil. Water containing less than $2 \mathrm{p} / \mathrm{m}$ of $\mathrm{K}$ was used for irrigation.

Soil samples from each pot were taken at the beginning and at the end of the experiment and analyzed for exchangeable and $\mathrm{HNO}_{3}$-soluble $\mathrm{K}$. In addition, all soil samples taken at the beginning of the experiment were analyzed for $\mathrm{pH}$, organic matter content, cation exchange capacity, and exchangeable $\mathrm{Ca}$ and $\mathrm{Mg}$.

To find out if the capacity of a soil to supply $\mathrm{K}$ as determined by cropping in pots is related to the actual $\mathrm{K}$ supplying capacity of the same soil under field conditions, field experiments were carried out concurrently with the greenhouse work. Three experiments were carried out at different locations on Múcara soil and one on Pandura soil over the same 4-yr. period. Two soil samples from each area of the field experiment were used in the pot experiment. Potassium supplying capacity of the soils in the field experiments was determined in the same way as in the pot study-by cutting the forage every 2 months and determining dry matter yield and $\mathrm{K}$ content of the forage. As in the pot experiment, the grass in all field experiments received $112 \mathrm{~kg}$ of $\mathrm{P} \mathrm{kg} / \mathrm{ha} . \mathrm{yr}$ in one application and $672 \mathrm{~kg} / \mathrm{ha}$.yr of $\mathrm{N}$ divided in 6 equal applications during the year. Plots were $4 \times 4 \mathrm{~m}$ had a solid stand of pangolagrass and were not irrigated.

\section{RESULTS AND DISCUSSIONS}

Table 1 shows that $\mathrm{pH}$ of the surface soil of these Inceptisols ranged from 5.35 to 6.70 and was slightly higher $(6.45-6.70)$ for the ustic than for the udic (5.5-6.3). Organic matter content of the surface soils ranged from 3.08 to 5.34 percent. Exchangeable $\mathrm{Ca}$ in the udic soils varied widelyfrom $3.91 \mathrm{meq} / 100 \mathrm{~g}$ in the Utuado and Pandura surface soil to 17.59 meq/100 $\mathrm{g}$ in the Caguabo soil. The ustic soils had exchangeable Ca contents exceeding $22 \mathrm{meq} / 100 \mathrm{~g}$ of soils. Exchangeable $\mathrm{Mg}$ also varied widely from a low of $1.38 \mathrm{meq} / 100 \mathrm{~g}$ in the Pandura and Utuado surface soils to between 6.78 and $12.62 \mathrm{meq} / 100 \mathrm{~g}$ of soil in the other soils. Exchangeable $\mathrm{K}$ contents ranged from 0.16 to 0.38 meq/100 in the udic surface soils to $.85 \mathrm{meq} / 100 \mathrm{~g}$ in the ustic soils. Cation exchange capacity of the surface soils also varied widely from 5.6 to $35.11 \mathrm{meq} / 100 \mathrm{~g}$ of soil as determined by sum of the cations, and from 7.40 to $34.67 \mathrm{meq} / 100 \mathrm{~g}$ of soil as determined by the ammonium acetate method.

Table 2 shows that the udic Inceptisols initially contained much less exchangeable $\mathrm{K}(195 \mathrm{~kg} / \mathrm{ha})$ and $\mathrm{HNO}_{3}$ soluble $\mathrm{K}(440 \mathrm{~kg} / \mathrm{ha})$ than the ustic, which had an average of $518 \mathrm{~kg} / \mathrm{ha}$ of exchangeable $\mathrm{K}$ and 1,410 $\mathrm{kg} / \mathrm{ha}$ of $\mathrm{HNO}_{3}$-soluble $\mathrm{K}$. On the average, the udic soils had a total of $635 \mathrm{~kg} / \mathrm{ha}$ of available $\mathrm{K}$ and the ustic $1,928 \mathrm{~kg} / \mathrm{ha}$.

On the average, Pangolagrass extracted a total of $610 \mathrm{~kg}$ of $\mathrm{K} / \mathrm{ha}$ from 
TABLE 1.-Chemical properties of the nine upland Inceptisols studied

\begin{tabular}{|c|c|c|c|c|c|c|c|}
\hline \multirow[b]{2}{*}{ Soil series } & \multirow[b]{2}{*}{$\mathrm{pH}$} & \multirow{2}{*}{$\begin{array}{l}\text { Organic } \\
\text { matter }\end{array}$} & \multicolumn{3}{|c|}{ Exchangeable bases } & \multicolumn{2}{|c|}{ Exchange capacity } \\
\hline & & & $\mathrm{Ca}$ & $\mathrm{Mg}$ & $\mathrm{K}$ & $\begin{array}{l}\text { Sum of } \\
\text { cations }\end{array}$ & $\begin{array}{l}\mathrm{NH}_{4} \mathrm{OAc} \\
\text { extraction }\end{array}$ \\
\hline & & & \multicolumn{3}{|c|}{$\mathrm{Me} / 100 \mathrm{~g}$ soil } & \multicolumn{2}{|c|}{$\mathrm{Me} / 100 \mathrm{~g}$ soil } \\
\hline Múcara-surface & 5.85 & 4.89 & 15.21 & 11.59 & .38 & 27.18 & 29.78 \\
\hline Múcara-subsoil & 6.00 & 2.96 & 16.16 & 12.52 & .18 & 28.86 & 30.36 \\
\hline Quebrada-surface & 6.00 & 4.06 & 17.18 & 12.62 & .30 & 30.1 & 31.07 \\
\hline Quebrada-subsoil & 6.00 & 2.38 & 18.33 & 12.00 & .17 & 30.5 & 31.40 \\
\hline Caguabo-surface & 6.30 & 3.96 & 17.59 & 9.49 & .37 & 27.45 & 26.15 \\
\hline Caguabo-subsoil & 6.05 & 2.07 & 17.31 & 8.95 & .26 & 26.52 & 26.03 \\
\hline Sabana-surface & 5.60 & 3.78 & 9.94 & 6.78 & .33 & 17.05 & 20.13 \\
\hline Sabana-subsoil & 5.50 & 2.10 & 10.38 & 8.12 & .25 & 18.75 & 20.74 \\
\hline Pandura-surface & 5.85 & 3.08 & 3.91 & 1.38 & .31 & 5.60 & 7.40 \\
\hline Pandura-subsoil & 5.65 & 1.82 & 3.38 & 1.28 & .25 & 4.91 & 7.31 \\
\hline Utuado-surface & 5.70 & 2.91 & 4.86 & 2.98 & .15 & 8.55 & 10.71 \\
\hline Utuado-subsoil & 5.65 & 1.30 & 5.01 & 2.68 & .08 & 8.27 & 10.12 \\
\hline Juncos-surface & 5.35 & 4.07 & 14.04 & 10.25 & .16 & 24.45 & 29.93 \\
\hline Juncos-subsoil & 5.70 & 2.90 & 14.60 & 13.80 & .08 & 28.48 & 30.06 \\
\hline Jácana-surface & 6.45 & 5.34 & 22.96 & 11.29 & .86 & 35.11 & 34.67 \\
\hline Jácana-subsoil ${ }^{1}$ & 6.75 & 3.76 & 27.52 & 12.37 & .37 & 40.26 & 35.91 \\
\hline Descalabrado-surface & 6.70 & 5.12 & 22.48 & 11.03 & .84 & 34.35 & 30.75 \\
\hline Descalabrado-subsoil ${ }^{1}$ & 6.65 & 3.36 & 23.72 & 10.09 & .34 & 34.15 & 30.16 \\
\hline
\end{tabular}

${ }^{1}$ The subsoil of Descalabrado and Jácana soils contain some free carbonates. 
TABLE 2.-Potassium extracted from nine upland Inceptisols during 4 years of continuous cropping with Pangola grass in pots and before and after four croppings

\begin{tabular}{|c|c|c|c|c|c|c|c|c|}
\hline \multirow[b]{2}{*}{ Soil type } & \multirow{2}{*}{$\begin{array}{l}\text { Sites } \\
\text { studied }\end{array}$} & \multicolumn{3}{|c|}{$\mathrm{K}$ in soil at start of the experiment } & \multirow{2}{*}{$\begin{array}{l}\text { K extracted by } \\
\text { cropping with } \\
\text { Pangola }\end{array}$} & \multicolumn{3}{|c|}{$\mathrm{K}$ in soil after 4 years of cropping } \\
\hline & & $\begin{array}{l}\text { Exchange- } \\
\text { able K }\end{array}$ & $\begin{array}{l}\mathrm{HNO}_{3} \mathrm{ex}- \\
\text { tractable K }\end{array}$ & $\begin{array}{l}\text { Total avail- } \\
\text { able K }\end{array}$ & & $\begin{array}{l}\text { Exchange- } \\
\text { able K }\end{array}$ & $\begin{array}{l}\mathrm{HNO}_{3} \text { ex- } \\
\text { tractable K }\end{array}$ & $\begin{array}{l}\text { Total avail- } \\
\text { able K }\end{array}$ \\
\hline Udic & Number & $K g / h a$ & $K g / h a$ & $K g / h a$ & $\mathrm{Kg} / \mathrm{ha}$ & $K g / h a$ & $K g / h a$ & $K g / h a$ \\
\hline Múcara & & & & & & & & \\
\hline $\begin{array}{l}\text { Vertic Eutropepts } \\
\text { Quebrada }\end{array}$ & 25 & 271 & 333 & 604 & 779 & 108 & 264 & 372 \\
\hline $\begin{array}{l}\text { Typic Eutropepts } \\
\text { Caguabo }\end{array}$ & 13 & 212 & 545 & 757 & 561 & 102 & 368 & 470 \\
\hline $\begin{array}{l}\text { Lithic Eutropepts } \\
\text { Sabana }\end{array}$ & 13 & 185 & 284 & 469 & 647 & 99 & 287 & 386 \\
\hline $\begin{array}{l}\text { Lithic Distropepts } \\
\text { Pandura }\end{array}$ & 10 & 248 & 272 & 520 & 632 & 90 & 183 & 273 \\
\hline $\begin{array}{l}\text { Typic Eutropepts } \\
\text { Utuado }\end{array}$ & 14 & 240 & 1102 & 1342 & 784 & 68 & 760 & 828 \\
\hline $\begin{array}{l}\text { Typic Humitropepts } \\
\text { Juncos }\end{array}$ & 7 & 99 & 208 & 307 & 496 & 62 & 184 & 246 \\
\hline Vertic Eutropepts & 7 & 110 & 336 & 446 & 371 & 91 & 235 & 326 \\
\hline Average for Udic & & 195 & 440 & 635 & 610 & 89 & 326 & 415 \\
\hline $\begin{array}{l}\text { Ustic } \\
\text { Jácana } \\
\text { Vertic Ustropepts } \\
\text { Descalabrado } \\
\text { Lithic Vertic }\end{array}$ & 5 & 568 & 1597 & 2165 & 1083 & 195 & 1272 & 1467 \\
\hline Ustropepts & 17 & 467 & 1223 & 1690 & 1188 & 137 & 641 & 778 \\
\hline Average for Ustic & & 518 & 1410 & 1928 & 1136 & 166 & 957 & 1123 \\
\hline Overall average & & 267 & 656 & 922 & 726 & 106 & 466 & 572 \\
\hline
\end{tabular}


TABLE 3.-Annual yields, $K$ contents, and $K$ uptake by Pangola grass growing in pots filled with nine upland Inceptisols during a 4-year period

\begin{tabular}{|c|c|c|c|c|c|c|c|c|c|c|c|c|c|c|c|c|}
\hline \multirow[b]{2}{*}{ Soils } & \multicolumn{3}{|c|}{ First year } & \multicolumn{3}{|c|}{ Second year } & \multicolumn{3}{|c|}{ Third year } & \multicolumn{3}{|c|}{ Fourth year } & \multicolumn{3}{|c|}{ Average for 4 years } & \multirow{2}{*}{$\begin{array}{c}\text { Average } \mathrm{K} \\
\text { uptake dur- } \\
\text { ing last } 3 \\
\text { years }\end{array}$} \\
\hline & $\begin{array}{l}\text { Dry } \\
\text { matter } \\
\text { yield }\end{array}$ & $\begin{array}{l}\mathrm{K} \\
\text { con- } \\
\text { tent }\end{array}$ & $\begin{array}{l}\mathrm{K} \text { up- } \\
\text { take }\end{array}$ & $\begin{array}{l}\text { Dry } \\
\text { matter } \\
\text { yield }\end{array}$ & $\begin{array}{c}\mathrm{K} \\
\text { con- } \\
\text { tent }\end{array}$ & $\begin{array}{l}\mathrm{K} \text { up- } \\
\text { take }\end{array}$ & $\begin{array}{c}\text { Dry } \\
\text { matter } \\
\text { yield }\end{array}$ & $\begin{array}{l}\mathrm{K} \\
\text { con- } \\
\text { tent }\end{array}$ & $\begin{array}{l}\mathrm{K} \text { up- } \\
\text { take }\end{array}$ & $\begin{array}{l}\text { Dry } \\
\text { matter } \\
\text { yield }\end{array}$ & $\begin{array}{c}K \\
\text { con- } \\
\text { tent }\end{array}$ & $\underset{\text { take }}{\mathrm{K} \text { up- }}$ & $\begin{array}{l}\text { Dry } \\
\text { matter } \\
\text { yield }\end{array}$ & $\begin{array}{c}\mathrm{K} \\
\text { con- } \\
\text { tent }\end{array}$ & $\underset{\text { take }}{\text { K up- }}$ & \\
\hline & $\mathrm{Kg} / \mathrm{ha}$ & $\%$ & $\mathrm{Kg} / \mathrm{ha}$ & $K g / h a$ & $\%$ & $K g / h a$ & $K g / h a$ & $\%$ & $\mathrm{Kg} / \mathrm{ha}$ & $\mathrm{Kg} / \mathrm{ha}$ & $\%$ & $K g / h a$ & $\mathrm{Kg} / \mathrm{ha}$ & $\%$ & $\mathrm{Kg} / \mathrm{ha}$ & $\mathrm{Kg} / \mathrm{ha} / \mathrm{yr}$ \\
\hline \multicolumn{17}{|c|}{ Udic Inceptisols } \\
\hline Múcara & 43,613 & .87 & 379 & 32,397 & .47 & 151 & 35,220 & .38 & 134 & 29,575 & .39 & 115 & 35,201 & .55 & 195 & 133 \\
\hline Quebrada & 40,192 & .71 & 284 & 29,492 & .33 & 96 & 30,902 & .30 & 94 & 25,770 & .34 & 87 & 31,589 & .44 & 140 & 92 \\
\hline Caguabo & 43,182 & .63 & 272 & 33,059 & .40 & 133 & 35,992 & .37 & 134 & 29,267 & .37 & 108 & 35,375 & .46 & 162 & 125 \\
\hline Sabana & 41,824 & .91 & 380 & 28,820 & .34 & 97 & 25,885 & .33 & 86 & 20,870 & .33 & 69 & 29,350 & .54 & 158 & 84 \\
\hline Pandura & 41,355 & .86 & 354 & 36,423 & .44 & 159 & 37,358 & .41 & 152 & 27,577 & .43 & 119 & 35,678 & .55 & 196 & 143 \\
\hline Utuado & 32,675 & .61 & 198 & 26,818 & .33 & 87 & 33,553 & .37 & 124 & 27,572 & .32 & 87 & 30,155 & .41 & 124 & 99 \\
\hline Juncos & 33,239 & .55 & 181 & 17,456 & .29 & 50 & 25,078 & .29 & 73 & 21,164 & .32 & 67 & 24,234 & .38 & 93 & 63 \\
\hline Average & 39,440 & .71 & 279 & 29,209 & .38 & 110 & 31,998 & .36 & 114 & 25,970 & .36 & 93 & 31,654 & .47 & 153 & 106 \\
\hline \multicolumn{17}{|c|}{ Ustic Inceptisols } \\
\hline Jácana & 45,770 & .98 & 447 & 48,194 & .50 & 241 & 44,409 & .55 & 244 & 32,770 & .45 & 147 & 42,786 & .63 & 270 & 211 \\
\hline Descalabrado & 47,265 & 1.20 & 566 & 42,763 & .62 & 267 & 41,190 & .54 & 221 & 31,750 & .42 & 134 & 40,742 & .73 & 297 & 207 \\
\hline Average & 46,518 & 1.09 & 507 & 45,479 & .56 & 254 & 42,800 & .54 & 233 & 32,260 & .43 & 140 & 41,764 & .68 & 284 & 209 \\
\hline
\end{tabular}


the udic Inceptisols over a 4-yr period as compared with 1,136 kg of K/ha from the ustic Inceptisols. On the average, Pangolagrass extracted $96 \%$ of the total available $\mathrm{K}$ from the udic and $60 \%$ from the ustic Inceptisols. Available K extracted by Pangolagrass varied from 58\% from the Pandura to $162 \%$ form the Utuado soil.

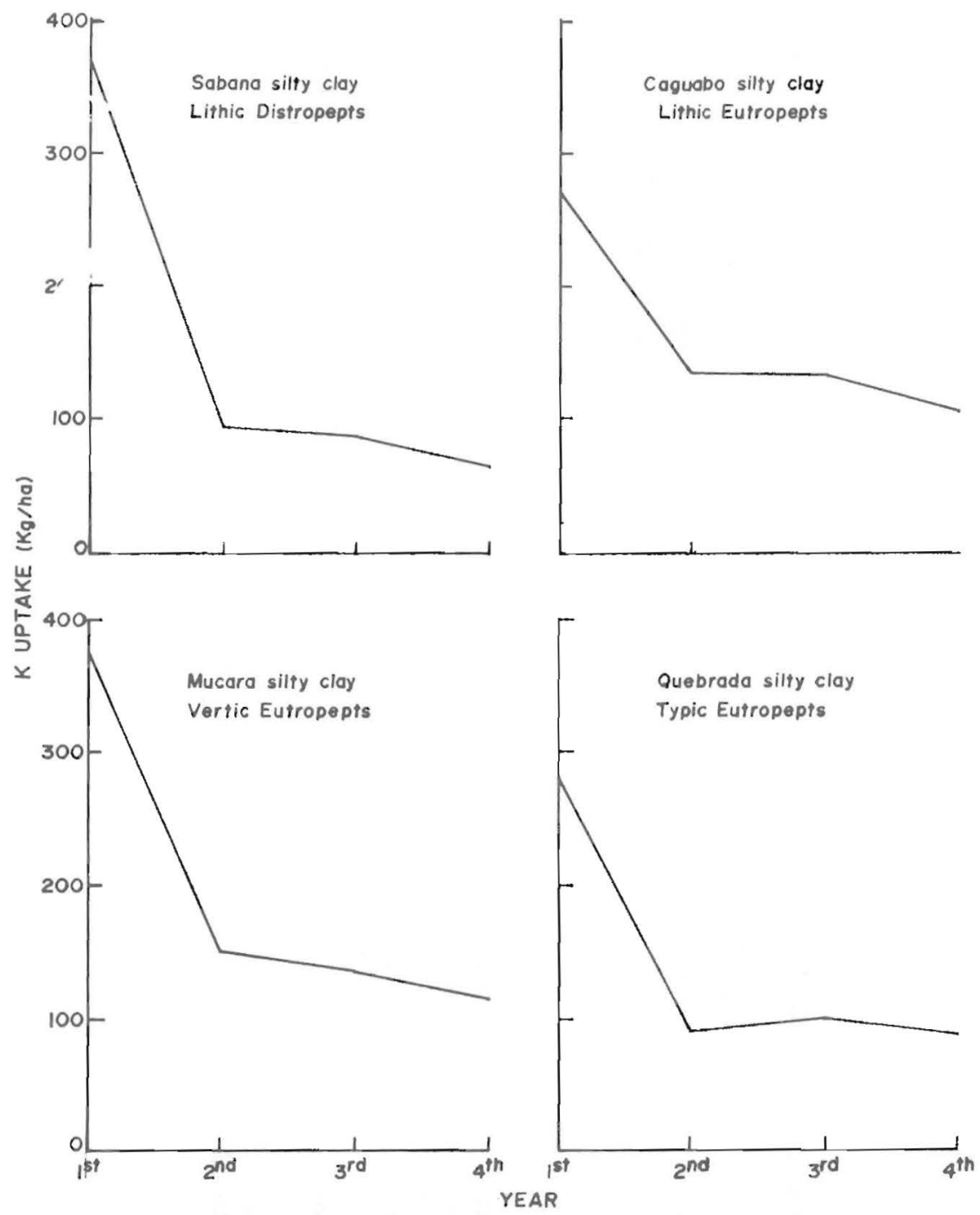

FIG. 2.-Potassium supplying power of the most important upland Udic Inceptisols from Puerto Rico as determined by intensive cropping with Pangola grass in pots over 4 consecutive years. 


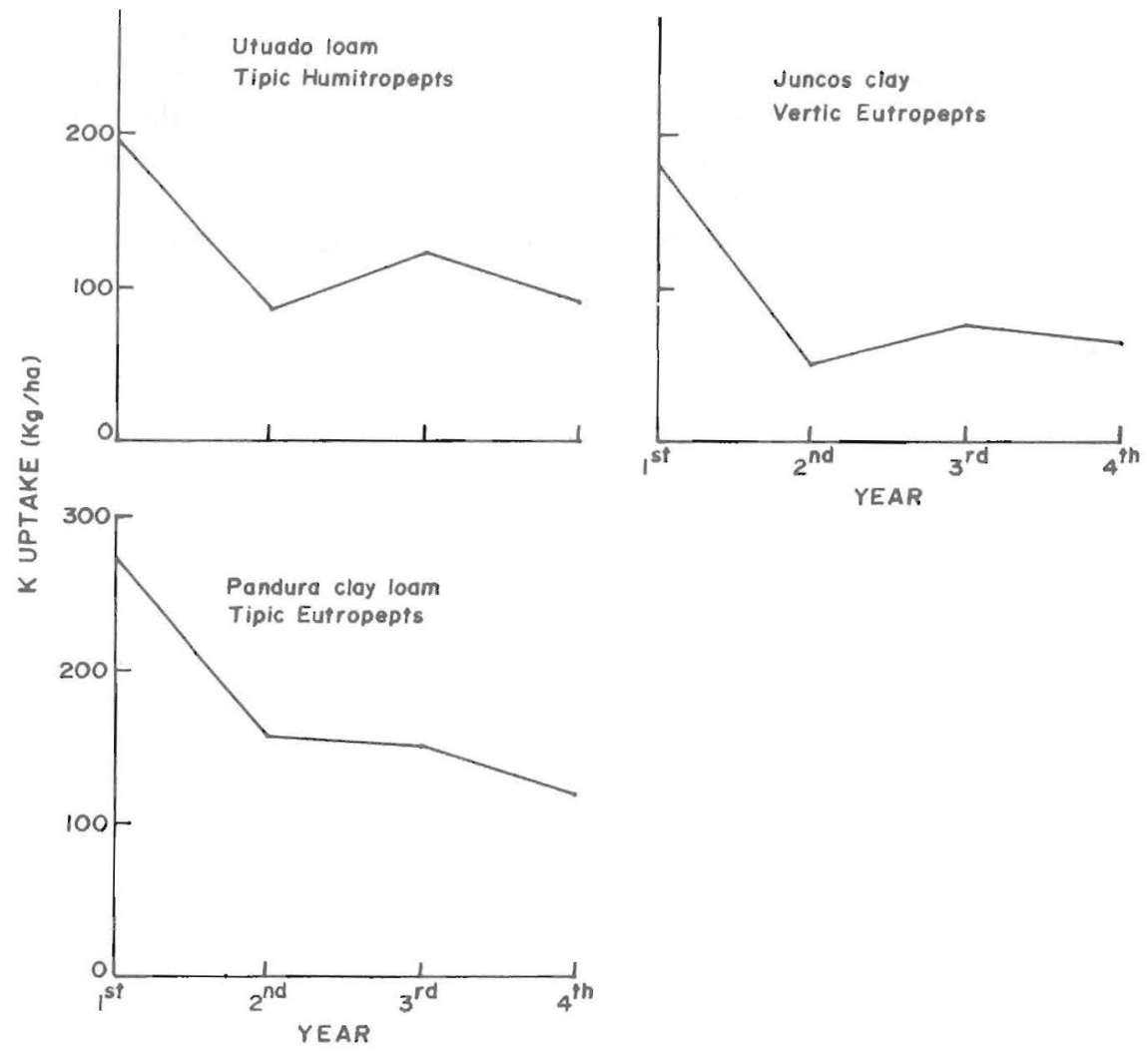

FIG, 2-Continued

At the end of 4 consecutive years of cropping with Pangolagrass, the udic Inceptisols still contained on the average $46 \%$ of the original exchangeable $\mathrm{K}$ content and $74 \%$ of the original $\mathrm{HNO}_{3}$-soluble $\mathrm{K}$ content. The ustic group had an average of $32 \%$ of original exchangeable $\mathrm{K}$ and $68 \%$ of the $\mathrm{HNO}_{3}$-soluble $\mathrm{K}$. After 4 consecutive years of cropping the soils as a group still contained $40 \%$ of the original exchangeable $\mathrm{K}$ content and $70 \%$ of the $\mathrm{HNO}_{3}$-soluble $\mathrm{K}$ content.

Table 3 and figure 2 show that $\mathrm{K}$ released to pangolagrass by the various soils during the first year was invariably high and dropped off sharply during subsequent years. There were marked differences in the amount of $\mathrm{K}$ extracted by pangolagrass among different udic Inceptisols, particularly during the first year. For example, during the first year of cropping the Múcara, Sabana and Pandura soils released over $350 \mathrm{~kg}$ of $\mathrm{K} / \mathrm{ha}$ whereas the Utuado and Juncos soils released only an average of $189 \mathrm{~kg}$ of $\mathrm{K} / \mathrm{ha}$. The Caguabo and the Sabana soils released an average of $278 \mathrm{~kg} / \mathrm{ha}$. Extraction during the last 3 years, ranged from 63 to $99 \mathrm{~kg} /$ 
ha.yr for Juncos, Quebrada, Sabana and Utuado soils and from 125 to $143 \mathrm{~kg} / \mathrm{ha}$.yr for Múcara, Caguabo, and Pandura soils. Abruña et al (2) found that upland Ultisols developed from parent material similar to that of Múcara, Caguabo, and Quebrada soils supplied about $90 \mathrm{~kg} / \mathrm{ha} . y \mathrm{r}$ to pangolagrass during 3 consecutive years of cropping.

The udic Inceptisols as a group released an average of $279 \mathrm{~kg}$ of $\mathrm{K} / \mathrm{ha}$

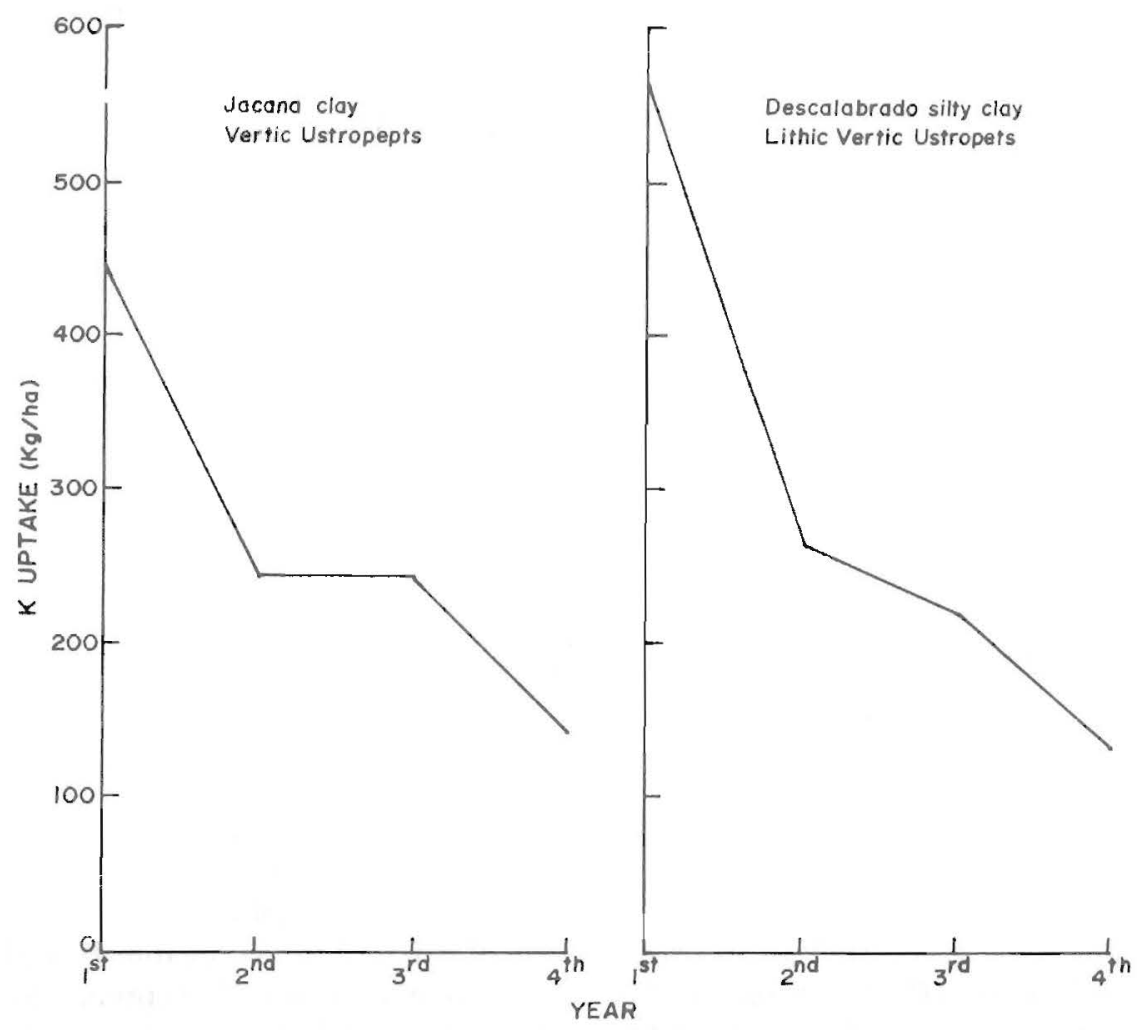

FIG. 3.-Potassium supplying power of the two most important upland Ustic Inceptisols from Puerto Rico as determined by intensive cropping with Pangola grass in pots over 4 consecutive years.

during the first year and then dropped to 110,114 and $93 \mathrm{~kg} / \mathrm{ha}$ for the second, third and fourth year, respectively. The average of $106 \mathrm{~kg} / \mathrm{ha}$ for the least 3 years probably represents the long term $\mathrm{K}$ supplying power of this group of soils (table 3 and figure 4 ).

Table 3 and figure 3 show that the two ustic Inceptisols, Descalabrado and Jácana, released 566 and $447 \mathrm{~kg}$ of $\mathrm{K} / \mathrm{ha}$.yr during the first year, respectively. During the last 3 years the Descalabrado soil released 267, 
221 and $134 \mathrm{~kg} / \mathrm{ha} . y r$ whereas the Jácana released 241, 244 and $147 \mathrm{~kg} /$ ha.yr, respectively.

During all years the ustic Inceptisols as a group released about twice as much $\mathrm{K}$ to Pangolagrass as did the udic group (Table 3 and figure 4). During the first year this group released an average of $507 \mathrm{~kg}$ of $\mathrm{K} / \mathrm{ha}$ followed by 254,233 and $140 \mathrm{~kg}$ of $\mathrm{K} / \mathrm{ha}$.yr for the last 3 years, respectively. The release patterns shown in figures 3 and 4 seem to indicate
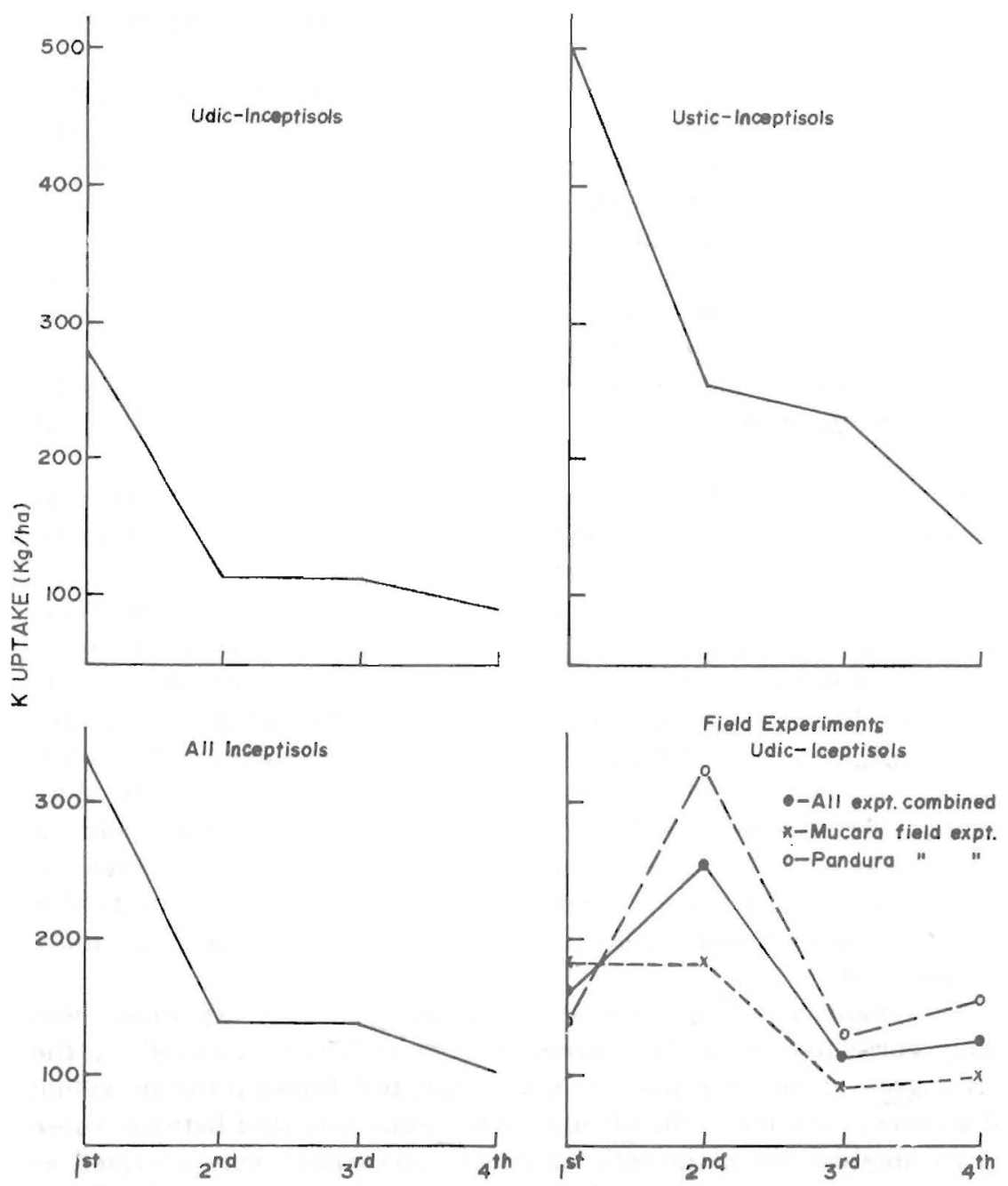

FIG. 4.-Potassium supplying power of Udic and Ustic groups of Inceptisols from Puerto Rico as determined by intensive cropping with Pangola grass in pots over 4 consecutive years. Field experiment data included for comparison. 
that the long range $\mathrm{K}$ supplying power of these soils may be in the neighborhood of $110 \mathrm{~kg}$ of $\mathrm{K} / \mathrm{h} a . y \mathrm{r}$.

Dry matter yields obtained in the pot experiment were substantially higher than those obtained under field conditions. Pangolagrass, on Múcara soil, under field conditions, produced 56, 81, 50 and $58 \%$ of the extrapolated yields of dry matter produced in pots during the 4 consecutive years of cropping with an average of $60 \%$ for the 4 years. On the Pandura soil, yields in the field experiment were 43, 97, 73 and $97 \%$ of those obtained in the pots. The average yield for the 4 cropping years was $75 \%$ of that obtained in pots.

In spite of lower forage yields obtained in the field experiments (table 4), K uptake was reasonably close to that obtained in the pot study. For example, the average $\mathrm{K}$ released by Múcara and Pandura soils in the pot experiment was $195 \mathrm{~kg} / \mathrm{ha}$ (table 3), whereas in the field experiments it was $170 \mathrm{~kg} / \mathrm{ha}$ (table 4). The $\mathrm{K}$ released by the Múcara soils in the pot experiment during the last 3 years of cropping averaged $133 \mathrm{~kg} / \mathrm{ha}$ whereas in the field experiments it amounted to $143 \mathrm{~kg} / \mathrm{ha}$. The total $\mathrm{K}$ released by Múcara soils in the pot experiment was $779 \mathrm{~kg} / \mathrm{ha}$ as compared with $626 \mathrm{~kg} / \mathrm{ha}$ for the field experiments. The Pandura soils released $784 \mathrm{~kg}$ of $\mathrm{K} / \mathrm{ha}$ in pots compared with $841 \mathrm{~kg} / \mathrm{ha}$ in the field experiment.

These results indicate that the data on $\mathrm{K}$ release by soils obtained in pot experiments are very similar to those obtained in field experiments which are much more difficult and expensive to conduct.

On the other hand, $\mathrm{K}$ content of pangolagrass under field conditions was considerably higher than that of pangolagrass growing in pots. Marked $\mathrm{K}$ deficiency symptoms occurred and yields were low when $\mathrm{K}$ content of the forage approached $0.60 \%$. In the pots pangolagrass produced much higher yields than in the field, yet did not exhibit deficiency symptoms even when the forage contained less than $0.4 \%$ of $\mathrm{K}$. Why pangolagrass must apparently contain more $\mathrm{K}$ to produce high yields in the field than in pots is not clear and suggests an area for further research. The grass growing in pots was wetted frequently, whereas in the field it suffered periodic drouths. Also pangolagrass in the pots received more reflected light.

The exchangeable $\mathrm{K}$ in the soil at the beginning of the experiment was closely correlated with the amount of this nutrient extracted by the pangolagrass during the first cropping year. Relationship for individual soil is shown in table 5. Significant correlations persisted between these two parameters when the udic and ustic Inceptisols were analyzed as separate groups, figure 5 and 6 . However, there was no significant correlation between the exchangeable $\mathrm{K}$ in the soil at the beginning of the experiment and the uptake of $\mathrm{K}$ during the last 3 years of cropping, 
TABLE 4.-Annual yield and potassium uptake by Pangola grass grown on 4 field experiments

\begin{tabular}{|c|c|c|c|c|c|c|c|c|c|c|c|c|c|c|c|c|c|c|}
\hline \multirow[b]{2}{*}{ Soil } & \multirow[b]{2}{*}{ Site } & \multicolumn{3}{|c|}{ First Year } & \multicolumn{3}{|c|}{ Second Year } & \multicolumn{3}{|c|}{ Third Year } & \multicolumn{3}{|c|}{ Fourth Year } & \multicolumn{4}{|c|}{ Average } & \multirow[b]{2}{*}{$\begin{array}{c}\text { Total } \\
\text { uptake }\end{array}$} \\
\hline & & $\underset{\text { matter }}{\text { Dry }}$ & $\begin{array}{l}\mathrm{K} \\
\text { con- } \\
\text { tent }\end{array}$ & $\underset{\text { take }}{\mathrm{K} \text { up- }}$ & $\underset{\text { matter }}{\text { Dry }}$ & $\begin{array}{c}\mathrm{K} \\
\text { con- } \\
\text { tent }\end{array}$ & $\underset{\text { take }}{\text { K up- }}$ & $\begin{array}{c}\text { Dry } \\
\text { matter }\end{array}$ & $\begin{array}{c}\mathrm{K} \\
\text { con- } \\
\text { tent }\end{array}$ & $\begin{array}{l}\mathrm{K} \text { up- } \\
\text { take }\end{array}$ & $\underset{\text { matter }}{\text { Dry }}$ & $\begin{array}{l}\mathrm{K} \\
\text { con- } \\
\text { tent }\end{array}$ & $\underset{\text { take }}{\mathrm{K} \text { up- }}$ & $\underset{\text { matter }}{\text { Dry }}$ & $\begin{array}{l}\mathrm{K} \\
\text { con- } \\
\text { tent }\end{array}$ & $\underset{\text { take }}{\mathrm{K} \text { up }}$ & $\begin{array}{c}\text { Average } \\
\mathrm{K} \text { uptake } \\
\text { for } 3 \mathrm{yr}\end{array}$ & \\
\hline & & $K g / h a$ & $\%$ & $\mathrm{Kg} / \mathrm{ha}$ & $\mathrm{Kg} / \mathrm{ha}$ & $\%$ & $K g / h a$ & $K g / h a$ & $\%$ & $K g / h a$ & $K g / h a$ & $\%$ & $K g / h a$ & $K g / h a$ & $\%$ & $K g / h a$ & $K g / h a$ & $K g / h a$ \\
\hline & Aguas Buenas & 19,086 & .50 & 96 & 23,263 & .65 & 150 & 18,191 & .58 & 105 & 19,990 & .55 & 111 & 20,133 & .57 & 115 & 122 & 462 \\
\hline & Saldaña & 25,099 & .78 & 195 & 37,331 & .77 & 287 & 24,929 & .54 & 136 & 15,553 & .61 & 95 & 25,729 & .69 & 178 & 172 & 717 \\
\hline & Orocovis & 29,130 & 1.02 & 296 & 18,377 & 1.04 & 192 & 10,032 & .77 & 77 & 15,529 & .91 & 141 & 18,267 & .97 & 177 & 137 & 706 \\
\hline \multicolumn{2}{|c|}{ Average for Múcara } & 24,438 & .80 & 196 & 26,324 & .80 & 209 & 17,717 & .60 & 106 & 17,024 & .68 & 115 & 21,376 & .73 & 157 & 143 & 626 \\
\hline Pandura & Yabucoa & 17,799 & .93 & 165 & 35,532 & 1.03 & 367 & 27,236 & .53 & 144 & 26,736 & .62 & 165 & 26,826 & .78 & 210 & 225 & 841 \\
\hline \multicolumn{2}{|c|}{ Average for all sites } & 22,779 & .83 & 188 & 28,626 & .87 & 249 & 20,096 & .58 & 115 & 19,452 & .66 & 128 & 22,739 & .75 & 170 & 164 & 680 \\
\hline
\end{tabular}


TABLE 5.-Relationship between various soil $K$ values and uptake of this nutrient by Pangolagrass growing in pots

\begin{tabular}{|c|c|c|c|c|c|}
\hline Soil & $\begin{array}{c}\text { Exch } \mathrm{K} \text { at the beginning vs } \mathrm{K} \\
\text { uptake during first year }\end{array}$ & $\begin{array}{l}\text { Exch } \mathrm{K} \text { at the beginning vs aver- } \\
\text { age } \mathrm{K} \text { uptake during last } 3 \text { years }\end{array}$ & $\begin{array}{l}\mathrm{HNO}_{3} \text { soluble } \mathrm{K} \text { at the begin- } \\
\text { ning vs average } \mathrm{K} \text { uptake dur- } \\
\text { ing last } 3 \text { years }\end{array}$ & $\begin{array}{l}\mathrm{HNO}_{3} \text { soluble } \mathrm{K} \text { at the end vs } \\
\mathrm{K} \text { uptake during last } 3 \text { years }\end{array}$ & $\begin{array}{c}\text { Total available } \mathrm{K} \text { vs total } \mathrm{K} \\
\text { extracted in } 4 \text { years }\end{array}$ \\
\hline Múcara & $r=.78^{* *}$ & Not & $\begin{aligned} r & =.66^{* *}\end{aligned}$ & $\begin{aligned} r=.60^{* *}\end{aligned}$ & $r=.88^{*}$ \\
\hline Quebrada & $\begin{array}{c}Y=-1090.23+638.90 \log _{n} x \\
\text { Not }\end{array}$ & $\begin{array}{l}\text { Signincant } \\
\text { Not }\end{array}$ & $\begin{array}{c}Y=-184.17+132.66 \log x \\
r=.84^{\circ}\end{array}$ & $\begin{array}{c}Y=-162.22+118.0 \log _{e} x \\
r=.88^{*}\end{array}$ & $\begin{array}{c}Y=-1216.11+686.4 \log _{e} x \\
r=.89^{* *}\end{array}$ \\
\hline \multirow{2}{*}{ Caguabo } & $\begin{array}{l}\text { Significant } \\
r=88^{*}\end{array}$ & $\begin{array}{l}\text { Significant } \\
r=.92^{* *}\end{array}$ & $\begin{array}{c}Y=-44.64+59.90 \log x \\
r=.74^{* *}\end{array}$ & $\begin{array}{c}Y=49.32+.106 x \\
r=67^{* *}\end{array}$ & $\begin{array}{c}Y=-1314.3+716.66 \log _{x} x \\
r=94^{* *}\end{array}$ \\
\hline & $Y=-2488.75+1245.87 \log _{e} x$ & $Y=52.6+.36 x$ & $Y=-331.90+200.85 \log _{e} x$ & $Y=20.4+.452 x$ & $Y=-824.66+533.42 \log _{e} x$ \\
\hline \multirow{2}{*}{ Sabana } & $r=.93^{* *}$ & $r=.78^{* *}$ & Not & Not & $r=.81^{\circ}$ \\
\hline & $Y=-69.74+1.84 x$ & $Y=42.23+.148 x$ & Significant & Significant & $Y=-142.95+1.52 x$ \\
\hline Juncos & $\begin{array}{c}r=.74^{* *} \\
Y=169+219 x-006 r^{2}\end{array}$ & $\begin{array}{c}\text { Not } \\
\text { Simifist }\end{array}$ & Not & Not & Not \\
\hline \multirow[t]{2}{*}{ Pandura } & $\begin{array}{c}Y=16.9+2.19 x-.006 x^{2} \\
r=.76^{* *}\end{array}$ & $\begin{array}{l}\text { Significant } \\
\text { Not }\end{array}$ & $\begin{array}{l}\text { Significant } \\
r=89^{* *}\end{array}$ & $\begin{array}{c}\text { Significant } \\
r=.62^{*}\end{array}$ & $\begin{array}{c}\text { Significant } \\
r=.80^{* *}\end{array}$ \\
\hline & $Y=-1505.76+800.0 \log _{e} x$ & Significant & $Y=36.72+.093 x$ & $Y=71.39+.083 x$ & $Y=12.9+.66 x$ \\
\hline Utuado & $\begin{array}{c}\text { Not } \\
\text { Significant }\end{array}$ & $\begin{array}{l}\text { Not } \\
\text { Significant }\end{array}$ & $\begin{array}{c}r=.72^{*} \\
Y=2.11+.465 x\end{array}$ & $\begin{array}{c}\text { Not } \\
\text { Significant }\end{array}$ & $\begin{array}{c}r=.81^{* 0} \\
Y=-171.68+2.25 x\end{array}$ \\
\hline \multirow[t]{2}{*}{ Jácana } & Not & Not & $r=.72^{* *}$ & $r=.74^{\circ}$ & Not \\
\hline & $\begin{array}{c}\text { Significant } \\
r=81^{* *}\end{array}$ & $\begin{array}{l}\text { Significant } \\
r=69^{* *}\end{array}$ & $\begin{array}{c}Y=125.90+.044 x \\
r=.85^{* \cdots}\end{array}$ & $\begin{array}{c}Y=115.02+.066 x \\
r=.86^{* *}\end{array}$ & $\begin{array}{c}\text { Significant } \\
r=84^{* \star}\end{array}$ \\
\hline Descalabrado & $Y=-49.47+1.89 x-.0009 x^{2}$ & $Y=-101.85+1.094 x-.0006 x^{2}$ & $Y=-734.77+320.37 \log x$ & $Y=51.82+.233 x$ & $Y=267.25+.53 x$ \\
\hline Udic Group & $\begin{array}{c}r=.75^{* *} \\
Y=-119643\end{array}$ & $\begin{aligned} r=.47^{*} \\
Y=67.0+.189 x\end{aligned}$ & $\begin{array}{c}r=.55^{* *} \\
Y=-122.27+9795\end{array}$ & $\begin{aligned} r=.45^{\circ *} \\
Y=7383+103 r\end{aligned}$ & $\begin{array}{r}r=.81^{* *} \\
Y=30491^{+}+486 x\end{array}$ \\
\hline \multirow[t]{2}{*}{ Ustic Group } & $\begin{array}{c}Y=-1196.43+679.10 \log _{e} x \\
r=.65^{* 0}\end{array}$ & $\begin{array}{r}Y=67.0+.189 x \\
r=.48^{*}\end{array}$ & $\begin{array}{c}Y=-122.27+97.95 \log _{e} t \\
r=.67^{* 0}\end{array}$ & $\begin{array}{r}Y=73.83+.103 x \\
r=.72\end{array}$ & $\begin{array}{r}Y=304.91+.486 x \\
r=.78^{\circ}\end{array}$ \\
\hline & $Y=-1305.58+707.31 \log _{e} x$ & $Y=88.50+.223 x$ & $Y=-580.50+266.43 \log _{x} x$ & $Y=81.82+.149 x$ & $Y=334.09+.44 x$ \\
\hline
\end{tabular}

Total available includes exchangeable $+\mathrm{HNO}_{3}$ soluble $\mathrm{K}$.
* Significant at the $5 \%$ level (Duncan's multiple range).

* Significant at the $5 \%$ level (Duncan's multiple range).
** Significant at the $1 \%$ level (Duncan's multiple range). 
except in the case of Caguabo and Sabana soils which showed a high correlation.

The $\mathrm{HNO}_{3}$-soluble $\mathrm{K}$ in the soil at the beginning of the experiment correlated with the average uptake of this nutrient by pangolagrass during the last 3 cropping years as shown in table 5 and figures 7 and 8 . In general, the $\mathrm{HNO}_{3}$-soluble $\mathrm{K}$ values did not correlate well with the

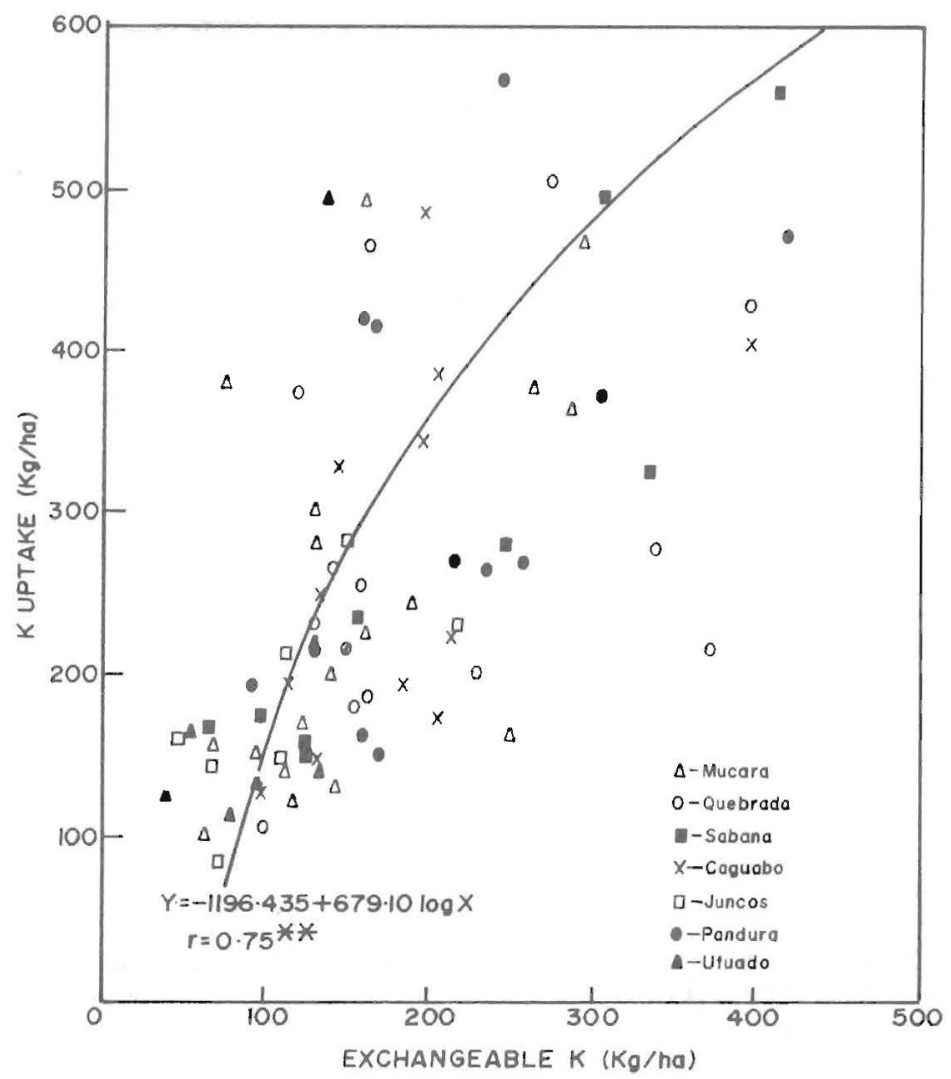

FIG. 5,-Relationship between the exchangeable $\mathrm{K}$ content of the most important Udic Inceptisols from Puerto Rico and uptake of this nutrient by Pangola grass during the first cropping year in pots.

uptake of $\mathrm{K}$ during the first year of cropping either when soils were considered individually or combined into groups. Only the Caguabo soil exhibited a good correlation between these $\mathrm{K}$ values (data not shown).

There was a highly significant correlation between the total available $\mathrm{K}$ (exchangeable $+\mathrm{HNO}_{3}$-soluble) determined at the beginning of the experiment and the total $\mathrm{K}$ uptake by Pangolagrass during the 4-year 


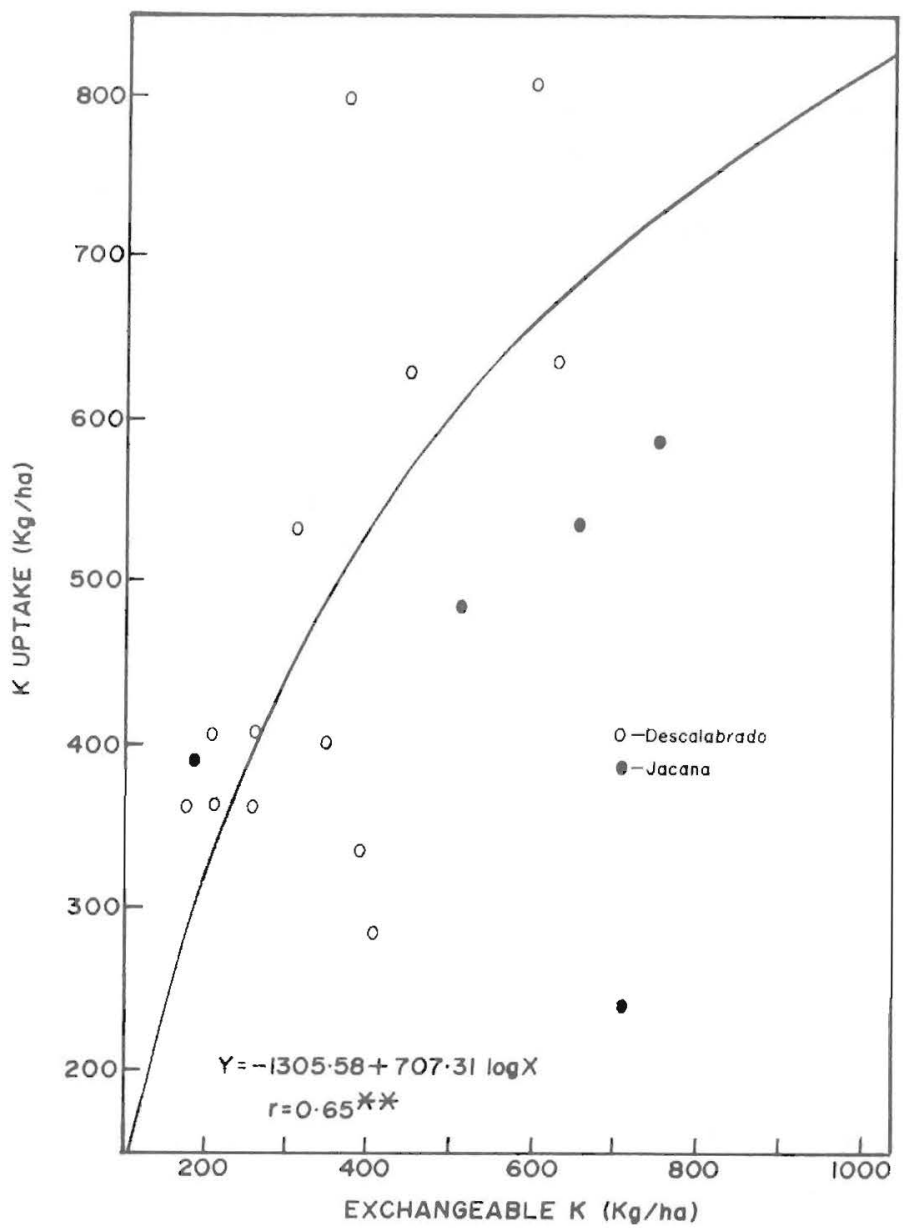

FIG. 6.-Relationship between the exchangeable $\mathrm{K}$ content of the most important Ustic Inceptisols from Puerto Rico and uptake of this nutrient by Pangola grass during first cropping year in pots.

cropping period. This correlation was exhibited both by individual soils (except Juncos and Jacana) and by the ustic and udic grass. In almost all cases $r$-values were over 0.8 .

After 4 years of cropping, the $\mathrm{HNO}_{3}$-soluble $\mathrm{K}$ left in the soil correlated significantly with the uptake of $\mathrm{K}$ during the last 3 years, both when soils were analyzed individually and in udic or ustic groups, except for Sabana, Juncos, and Utuado soils. This is further evidence that the $\mathrm{HNO}_{3}$-soluble $\mathrm{K}$ is a good indicator of the long term $\mathrm{K}$ supplying capacity of the upland Inceptisols from Puerto Rico. 


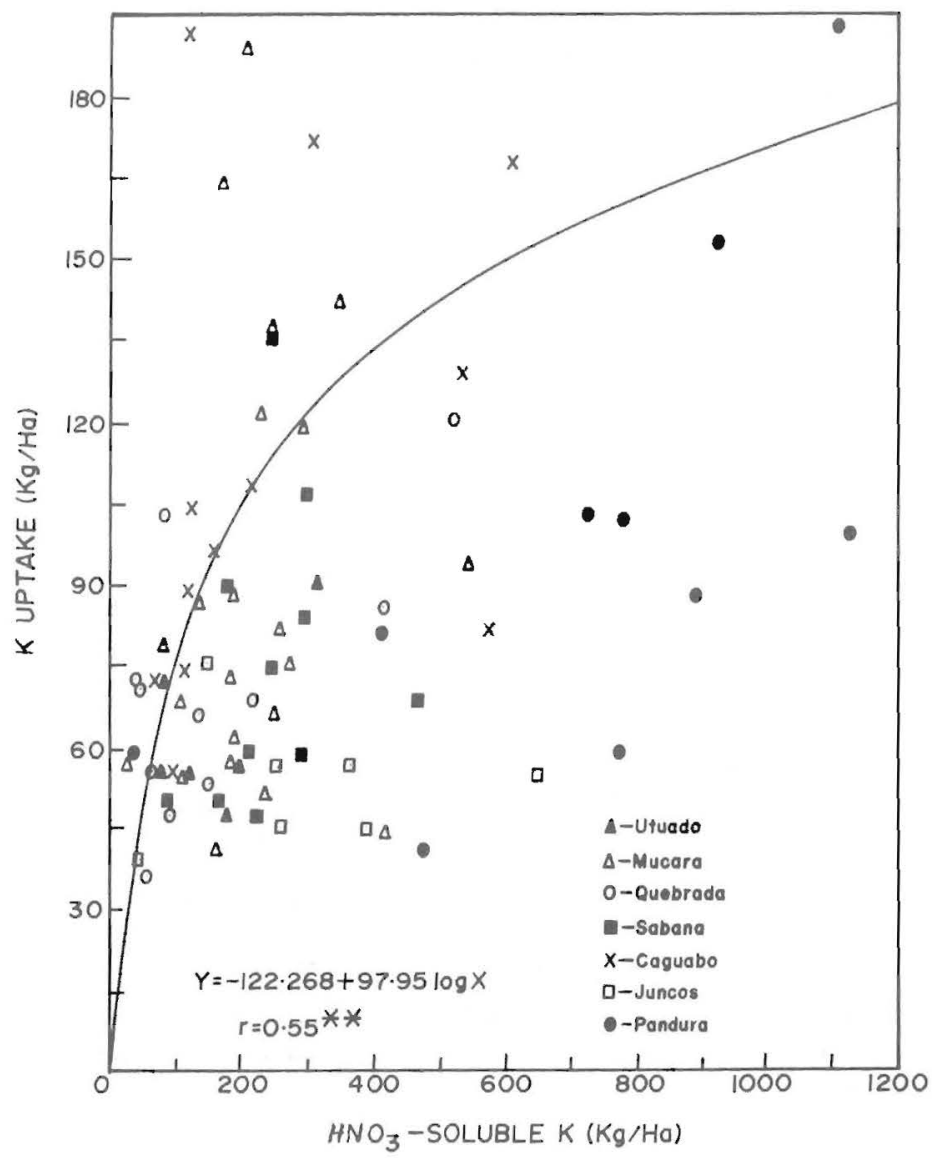

FIG. 7.-Relationship between the $\mathrm{HNO}_{3}$ soluble $\mathrm{K}$ content of the most important Udic Inceptisols and uptake of this nutrient by Pangola grass during the last 3 cropping years in pots.

The data presented show that exchangeable $\mathrm{K}$ is a good criterion for estimating the capacity of the udic Inceptisols to supply this nutrient to grasses during the first year and the $\mathrm{HNO}_{3}$-soluble $\mathrm{K}$ values provide a reasonable guide for predicting the long term supplying capacity of these soils. The ustic Inceptisols contain more exchangeable $\mathrm{K}$ than the udic and thus can supply $\mathrm{K}$ from this form for more than one year. However, the long term capacity of these soils to supply $\mathrm{K}$ can also best be predicted from their $\mathrm{HNO}_{3}$-soluble $\mathrm{K}$ contents.

It can be concluded that the udic Inceptisols from the uplands of Puerto Rico can supply on the average $279 \mathrm{~kg} / \mathrm{ha}$ of $\mathrm{K}$ during the first year, but the long term supplying power is around $100 \mathrm{~kg} / \mathrm{ha}$.yr. 


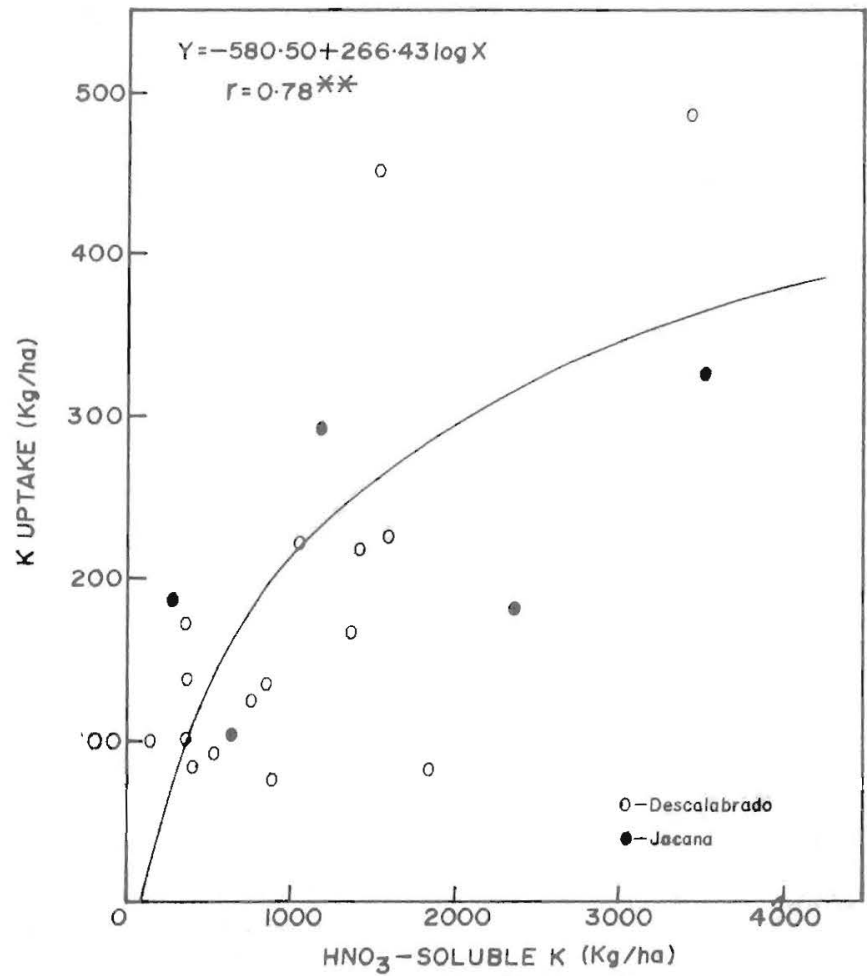

FIG. 8.-Relationship between the $\mathrm{HNO}_{3}$ soluble $\mathrm{K}$ content of the most important Ustic Inceptisols of Puerto Rico and uptake of this nutrient by Pangola grass during the last 3 cropping years in pots.

The ustic Inceptisols, which are richer in $\mathrm{K}$ than the udic group can supply about $500 \mathrm{~kg}$ of $\mathrm{K} / \mathrm{ha}$ during the first year and about $140 \mathrm{~kg} / \mathrm{ha}$.yr even after 4 years of continuous cropping.

\section{RESUMEN}

Se determinó la capacidad de los Inceptisoles de la altura de Puerto Rico para suplir $\mathrm{K}$ al pasto Pangola mediante un experimento en invernadero utilizando tiestos, y de cuatro experimentos de campo en suelos Múcara y Pandura.

El grupo Udic suplió en promedio $279 \mathrm{~kg} / \mathrm{ha}$ de $\mathrm{K}$ al pasto el primer año y luego disminuyó a 110,114 y $93 \mathrm{~kg} / \mathrm{ha}$ en el segundo, tercero y cuarto años, respectivamente. El promedio de $106 \mathrm{~kg} / \mathrm{ha}$ para los últimos 3 años parece ser un índice apropiado para estimar la capacidad de estos suelos para suplir $\mathrm{K}$ al pasto Pangola.

El grupo Ustic suplió en promedio $507 \mathrm{~kg} / \mathrm{ha}$ de $\mathrm{K}$ el primer año. En 
los 3 años siguientes las cantidades fueron de 254, 233 y $140 \mathrm{~kg} / \mathrm{ha}$ para el segundo, tercero y cuarto años, respectivamente. Aunque el promedio para los últimos 3 años fue de $209 \mathrm{~kg} / \mathrm{ha}$ la continua disminucion en la cantidad de $\mathrm{K}$ extraída por el pasto, parece indicar que la capacidad de estos suelos para suplir $\mathrm{K}$ a largo plazo a las cosechas debe ser menor.

La cantidad de $\mathrm{K}$ que extrajo el pasto Pangola de los suelos Pandura y Múcara en el experimento en invernadero corresponde bastante fielmente con los valores obtenidos en los experimentos de campo.

El contenido en $\mathrm{K}$ cambiable del suelo al comienzo del experimento se correlacionó significativamente con la cantidad de este elemento nutritivo extraido por el pasto Pangola el primer año, mientras que el K soluble en ácido nítrico se correlacionó en forma significativa con la cantidad media de $\mathrm{K}$ extraida por el pasto en los últimos 3 años de experimentación.

\section{LITERATURE CITED}

1. Abruña, F., Vicente-Chandler, J., Becerra, L. A., and Bosque-Lugo, R., 1965. Effects of liming and fertilization on yields and foliar composition of high-yielding sun grown coffee in Puerto Rico. J. Agr. Univ. P.R., 49 (4) 413-428.

2. Abruña, F., Vicente-Chandler, J., Figarella, J., and Silva, S., 1976. Potassium supplying power of the major Ultisols and Oxisols of Puerto Rico. J. Agr. Univ. P.R. 60 (1) 4560.

3. Acquaye, D. K., Maclean, A. J., and Rice, H. M., 1967. Potential and capacity of potassium in some representative soils of Ghana. Soil Sci. 103: 79-89.

4. Ahenkorah, Y., 1970. Potassium supplying power of some soils of Ghana cropped to cacao. Soil Sci. 109: 127-135.

5. Boyer, J., 1972. Soil potassium. In Soils of the Humid Tropics. National Academy of Science, Washington, D. C.

6. Breland, H. L., Bertramson, B. R., and Borland, J. W., 1950. Potassium-supplying power of several Indiana soils. Soil Sci. 70: 237-247.

7. Bray, R. H. and De Turk, E. E., 1939. The release of potassium from nonexchangeable forms in Illinois soils. Soil Sci. Am. Proc. 3: 101-106.

8. Buridge, J. C., Lockard, R. G., and Acquaye, D. K., 1963. Shade and fertility experiments-foliar analysis. Rep. West Afr. Cocoa Res. Inst. 1961-62, Tafo, Ghana.

9. Caro-Costas, R., Abruña, F., and Vicente-Chandler, J., 1964. Response to fertilization of strip-cultivated plantains growing on a steep latosol in the humid mountain region of Puerto Rico. J. Agr. Univ. P.R., 48 (4) 312-317.

10. Chandler, R. F., Peech, M., and Chang C. W., 1945. The release of exchangeable and non exchangeable K from different soils upon cropping. Am. Soc. Agr. 37: 709-721.

11. Evans, C. E. and Attoe, O. J., 1948. Potassium supplying power of vergin and cropped soils. Soil Sci. 66: 323-334.

12. Moss, P. and Coulter, J. K., 1964. Potassium status of west indian volcanic soils. Jour. Soil Sci. 15 (2) 284-298.

13. Oelsligle, D. D., Doll, E. C., and Valverde, C., 1975. Potassium release characteristics of selected Peruvian soils. Soil Sci. Soc. Am. Proc. 39: 891-895.

14. Pearson, R. W., 1952. Potassium supplying power of eight Alabama soils, Soil Sci. 74: 301-309.

15. Ransnake, M. and Thomas, W. W., 1976. Potassium status of some alluvial soils of Kentucky. Soil Sci. Soc. Am. Proc. 40: 883-886. 
16. Rich, C. I., 1968. Mineralogy of soil potassium. In the Role of Potassium in Agriculture published by Am. Soc. of Agr., Madison, Wisc.

17. Rouse, R. D. and Bertramson, B. R., 1949. Potassium availability in several Indiana soils, its nature and method of evaluation. Soil Sci. Am. Proc. 14: 113-123.

18. Tinker, P. B., 1964. Studies on soil potassium. III. Cation activity ratios in acid Nigerian soils. J. Soil Sci. 15: 24-34.

19. Vicente-Chandler, J., Pearson, R. W., Abruña, F., and Silva, S., 1962. Potassium fertilization of intensively managed grasses under humid tropical conditions. Agr. J. 54 (5) $450-453$.

20. Wiklander, L., 1954. Forms of potassium in the soil p. 109-121. In Potassium Symposium. Int. Potash Inst., Bern, Switzerland. 